eyes or call for examination and report on the condition of the eyes, and that the society should refer the patients to an ophthalmologist on the approved list. This "approved list" is to be supplied and maintained by the British Medical Association, and is to contain the names of medical practitioners who satisfy certain now familiar criteria which will be found in detail in paragraph 24 of the Evidence of the Association, presented to the Royal Commission on National Health Insurance (Supplement, February 28, 1925, p. 73 ). Besides satisfying these criteria doctors on the list must be willing to accept an inclusive fee of $£ 11 \mathrm{~s}$. for each insured person sent to them by approved societies.

Lists of medical men who possess the necessary qualifications and are willing to undertake the work, are being prepared by the British Medical Association, and names should be sent in to the secretary of the British Medical Association. These lists at present contain about 500 names.

\title{
CONVENTION OF ENGLISH-SPEAKING OPHTHALMOLOGICAL SOCIETIES
}

\author{
To Be held in London, July 14, 15, 16 and 17, 1925. \\ Under the auspices of the Ophthalmological Society of \\ the United Kingdom and its Affiliated Societies.
}

The full programme of this Convention to be held in London on July 14, 15, 16, and 17,1925, is now in our hands. The President is Mr. E. Treacher Collins; the General Secretary, Mr. C. B. Goulden; the Secretary of the Committee for Scientific Business and Publications, Mr. R. Foster Moore; of the Committee for General Arrangements and Entertainments, Mr. J. F. Cunningham; of the Committee for Finance and Registration, Mr. Leslie Paton; of the Banquet Committee, Mr. M. S. Mayou; of the Museum Committee, Miss Ida Mann.

The following members of affiliated Societies will be willing to assist overseas members who, after the Convention, are desirous of visiting the parts of the country mentioned:

Oxford.-P. H. Adams, The Cardinal's Hat, 6, Holywell, Oxford.

Cambridge.-Arthur Cooke, Grove Lodge, Cambridge.

North of England Ophthalmological Society. - P. J. Hay, 35, Glossop Road, Sheffield. 


\section{The British Journal of Ophthalmology}

Midland Ophthalmological Society. - H. W. Archer-Hall, 54, Newhall Street, Birmingham.

For Birmingham.-J. Jameson Evans, 41, Newhall Street, Birmingham.

For Leamington, Stratford-on-Avon and Coventry.-T. Harrison Butler, 81, Edmund Street, Birmingham.

For Sulgrave Manor.-E. Harries-Jones, 16, Castilian Street, Northampton.

For Worcester.-B. H. St. Clair Roberts, Cwm House, Castle Street, Worcester.

Scottish Ophthalmic Club. - W. C. Souter, 9, Albyn Place, Aberdeen; E. H. Cameron, 7, Darnaway Street, Edinburgh ; James Conway, D.S.O., M.C., 36, Berkeley Street, Glasgow.

Irish Ophthalmological Society.--Louis Werner, 31, Merrion Square North, Dublin; W. C. MacFétridge, 27, Upper Fitzwilliam Street, Dublin.

\section{NOTICE}

The Convention will be held at University College, London (Gower Street, W.C.1).

The Registration Bureau, Thos. Cook \& Son's Office, The Scientific Museum and the Trades Exhibition will be in the Anatomical Department, the entrance to which is in Gower Street. The Meetings will be held in the Memorial Hall.

On arrival, every member of the Convention is requested to attend as soon as possible at the Registration Bureau and enter his or her name and address during the Convention.

Those who have not already paid their membership fee are requested to do so to Mr. Leslie Paton, 29, Harley Street, London, W.1, without further delay. Cheques to be made payable to the Treasurer, Sir Arnold Lawson.

Those wishing to read papers before the Convention are requested to communicate with Mr. Foster Moore, 91, Harley Street, London, W.1, at an early date. A typewritten copy of the paper with an abstract suitable for immediate publication must be sent in before June 14.

No paper will be accepted which has been published elsewhere, and no communication to the Convention must occupy more than twenty minutes. In order to prevent the crowding out of papers and to allow of discussion it will be necessary that this time limit be strictly adhered to. This, however, will not preclude the publication of longer papers in full in the Transactions.

The Scientific Museum Committee appeal for the loan of suitable material illustrative of all aspects of ophthalmic work. Macroscopical and microscopical specimens, drawings, photographs, instruments, charts and diagrams will be welcome. They will be arranged in subdivisions, amongst others, Human and Comparative Anatomy, Embryology and Pathology, Congenital Anomalies, Historical Instruments and Portraits. Those willing to contribute are requested to communicate as early as possible with Mr. Affleck Greeves, 23, Wimpole Street, London, W.1.

Mr. C. J. Anderson has been appointed Controller of the Trades Exhibition; all enquiries connected with it should be addressed to him at 5, Racquet Court, Fleet Street, E.C.4.

Thos. Cook \& Son, Ltd., have been appointed official agents of the Convention in connection with travel and Hotel arrangements. Their office during the Convention will be in the Anatomical Department at University College. Tickets can be obtained there for the chars-a-bancs excursions to institutions of ophthalmic interest, and to Oxford and Cambridge. Other arrangements can also be made respecting transport or conveyance.

It is very desirable to know beforehand the number of members likely to attend some of the entertainments and excursions. All registered members who wish to 
participate in them are, therefore, requested to fill up and return the accompanying forms to the General Secretary, Mr. C. B. Goulden, 79, Portland Place, London, $\mathrm{W} .1$, as soon as possible.

\section{Programme}

\section{Monday, July 13}

9 p.m. to 12.-Reception at the Royal College of Surgeons of England, Lincoln's Inn Fields, by the President, Sir John Bland-Sutton and Council.

\section{Tuesday, July 14}

At the Memorial Hall, University College.

10 a.m. - Address of Welcome by the RT. HON. NEville ChAmberLaIN, Minister. of Health.

Reception of Delegates.

The American Ophthalmological Society. - Dr. G. E. de Schweinitz.

The American Medical Association, Ophthalmic Section.-Dr. W. R. Parker.

The American Academy of Ophthalmology and Oto-Laryngology.--Dr. Walter B. Lancaster.

The Toronto Academy of Medicine.-Prof. I. M. McCallum.

The Montreal Ophthalmological Society-Prof. W.G. M. Byers.

The Ophthalmological Section of the British Medical Association, Victoria, Australia.-Dr. J. Kingland Anderson.

Award of the Nettleship Prize to Professor S. E. Whitnall.

Presentation of the Critchett Memorial Presidential Badge.

President's Opening Address on "The Elimination of Eye Disease."

11 a.m. to 12.30 p.m.-Papers.

2 p.m.-Visits to Institutions of Ophthalmic interest, for which charsà-bancs will start from University College. Tickets to be obtained at the Registration Bureau.

Excursion I. (Limited to 100 members.)

1. St. Margaret's Hospital, Leighton Road, Kentish Town.

2. London County Council Myopia School, Sebbon Street, Upper Street, Islington.

3. Royal London Ophthalmic Hospital, Moorfields.

Excursion II. (Limited to 100 members.)

1. St. Dunstan's, Inner Circle, Regent's Park.

2. The Central London Ophthalmic Hospital.

Excursion III. (Limited to 50 members.)

1. Royal Westminster Ophthalmic Hospital.

2. National Library for the Blind, 18, Tufton Street, Westminster.

Excursion IV. (Limited to 100 members.)

1. The Royal Eye Hospital, St. George's Circus.

2. The Royal Normal College for the Blind, South Norwood.

Excursion V. (Limited to 50 members.)

White Oak Ophthalmia School, Swanley. 
8.30 p.m.- Reception at the Royal Institution of Great Britain, Albemarle Street, W., by the President, His Grace the Duke of Northumberland, and Managers.

9 p.m.--Sir William Bragg, K.B.E., D.Sc., F.R.S., the Director of the Institution, will deliver an address on "Thomas Young and his Work."

\section{Wednesday, July 15}

9 a.m. to 12.30 p.m.-At the Memorial Hall, University College.Papers.

3 p.m.-Garden Party, given by Sir William and Lady Lister, at Aubrey House, Campden Hill.

8.30 p.m.-At the Memorial Hall, University College. A Symposium on "The Evolution of Binocular Vision,"

By the following speakers :

Sir Charles Sherrington, O.M., G.B.E, P.R.S.

Sir Arthur Keith, F.R.S.

Sir Frederick Mott, K.B.E., F.R.S.

Prof. Elliot Smith, F.R.S.

Prof. S. E. Whitnall.

\section{Thursday, July 16}

9 a.m. to 12.30 p.m.- At the Memorial Hall, University College.Papers.

3 p.m.-General Meeting of the Convention at which the re-establishment of International Ophthalmological Congresses on the pre-war basis will be considered.

5 p.m. -The Bowman Lecture, by Sir John Herbert Parsons, C.B.E., F.R.S., "The Foundations of Vision."

8.30 p.m.-Reception at the Wellcome Historical Medical Museum, Wigmore Street, by the President of the Convention.

\section{Friday, July 17.}

9 a.m. to 12.30 p.m.-In the Memorial Hall, University College. Discussion on "The Microscopy of the Living Eye."

To be opened by :

Dr. Gordon Byers, of Montreal.

Dr. Arthur J. Bedell, of Albany, U.S.A.

Mr. Harrison Butler, of Birmingham.

Mr. Basil Graves, of London.

2 p.m. to 5 p.m.-Papers.

6.45 p.m. for 7 p.m.-Banquet at the Guildhall, King Street. City. Reception in the Art Gallery. H.R.H. the Duke of Connaught, K.G., has graciously consented to be the guest of the Convention. Tickets, to be obtained at the Bureau, price 35s. including wine. 


\section{Saturday, July 18}

EXCURSIONS TO OXFORD OR CAMBRIDGE.

Railway tickets at reduced fares can be obtained from Thos. Cook \& Son.

\section{OXFORD.}

Members will have the opportunity of lunching in Hall at Keble College, for which a small charge will be made.

The Members of the Oxford Ophthalmological Congress are arranging for parties to be personally conducted round the various colleges and other buildings of interest, and will afterwards entertain them at tea in the grounds of Magdalen College.

\section{CAMBRIDGE.}

Members will have the opportunity of lunching in Hall at Trinity College, for which a small charge will be made.

Parties will afterwards be conducted round the colleges and other buildings of interest.

The Vice-Chancellor of the University, Dr. Seward, will entertain a party of members at tea at Downing College.

The following is a list of the papers which have been already sent in, arranged alphabetically, in accordance with the names of the authors, and not in the order in which they will be taken:

G. F. Alexander.

(1) "Control of the Eye in Operations."

(2) "Ocular Physiological Torsion."

Mary Buchanan.

"A Case of Congenital Dermoid."

W. BURDON-COOPER.

"The Behaviour of the Crystalline Lens System in Artificial Cycloplegia and its Influence on Refraction."

T. HARRISON ButLER.

"Some Changes that are seen with the Slit-Lamp in Eyes that have been Injured or Operated upon."

E. C. Carmichael and P. Sargent.

"The Treatment of Pituitary Tumours."

ERnest Clarke.

"Myopia."

JAMES COLlier.

"Schilder's Encephalitis Periaxialis."

R. C. DAVEN PORT

$\therefore$ The Recovery of the Visual Fields in Pituitary Disease without Operation."

A. EDWARd Davis.

"The Lens Antigen Treatment of Cataract."

Frederick A. Davis.

" Hereditary Eye Defects in Rabbits Experimentally Produced."

GEORG: DERBY and J. HERBERT WAITE.

"The Light Sense in Glaucoma."

Alexander DuAne.

"Projection, Visual and Postural."

J. HERBERT FISHER.

"A Consideration of the Intra-ocular Lymph Paths."

L. WeBster Fox.

"Surgical Treatment of Conical Cornea."

HaRRY Friedenwald and Jonas S. FriedenWALd.

"The Preparation of an Aseptic Field for Operations on the Eye." 
D. V. GIRI.

" Some Remarks on Milk Injections together with Reports of Cases treated."

Clark W. Hawley.

" Retinoscopy.'

THOMSON HENDERSON.

"The Postural Activity and Evolution of the Ciliary Muscle: A Study of the Mechanism of Accommodation."

MALCOLM L. HePBURN.

"The Teaching of Ophthalmology."

H. HERBERT.

"Anatomical Predisposition to Glaucoma."

VAN DER HOEVE.

"Glioma Retinae."

P. Chalmers Jameson.

"Principles of Recession Operations and Scleral Fixation in the Correction of Squint."

E. L. JONES.

"The Advantage of Immediately Producing a Maximal Physiologic Lymphatic Reaction in Dangerously Wounded Eyes."

RICHARD KERRY.

"Pathogeny of Glaucoma."

ARNOLD KNAPP.

"Late Results of Intra-capsular Cataract Extraction."

H. Maxwell Langdon.

"The Blood Chemistry of Patients with Primary Cataracts."

F. PARK LEWIS.

"Preventive Ophthalmology, its Scope and Possibilities."

IDA C. MANN.

“The Embryology of the Lens and the Correlation of it with Slit-Lamp Appearances.'

M. S. Mayou.

"Siderosis."

R. Foster Moore.

"An Intra-cranial Unruptured Aneurysm. Diagnosed during Life, which had caused Rupture of the Optic Nerve."

Leslie Paton and Ida C. Mann.

"The Development of the Oculo-motor Nuclei."

J. N. RHOADES.

"Precise Vernier Axis Finder."

JOHN Rowan.

"Glaucoma: Thrombosis of the Central Vein as the Cause of a Failure of Successful Iridectomy after 17 years."

A. H. H. Sinclair.

"Intra-capsular Extraction of Cataract with some New Instruments, and Cinematograph Demonstration."

DAVID W. WELLS.

"The Training of the Fusion Faculty."

F. A. Williamson-Noble.

"An Unusual Case of Irido-cyclitis."

Alan C. Woods.

"Sympathetic Ophthalmia."

R. E. WRIGHT.

"A Rare Congenital Bilateral Malformation of the Conjunctiva."

S. LEWIS ZIEGLER.

"History of Discission; Complete Division of the Lens by the $\mathbf{V}$-shaped Method." 